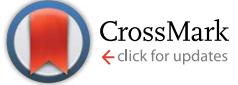

Cite this: RSC Adv., 2015, 5, 24729

Received 27th November 2014 Accepted 19th February 2015

DOI: $10.1039 / c 4 r a 15383 a$

www.rsc.org/advances

\section{New insight into rare-earth doped gadolinium molybdate nanophosphor assisted broad spectral converters from UV to NIR for silicon solar cells $\dagger$}

\begin{abstract}
Pawan Kumar ${ }^{\mathrm{ab}}$ and Bipin Kumar Gupta*a
We have successfully synthesized rare-earth doped gadolinium molybdate $\mathrm{Gd}_{2}\left(\mathrm{MoO}_{4}\right)_{3}: \mathrm{Re}^{3+}\left(\mathrm{Re}^{3+}=\mathrm{Eu}^{3+}\right.$, $\mathrm{Tb}^{3+}, \mathrm{Tm}^{3+}$ and $\mathrm{Er}^{3+} / \mathrm{Yb}^{3+}$ ) nanophosphors for solar cell application as a broad spectral converter from the ultraviolet (UV) to the near infrared (NIR) regions in a single host lattice using a facile solid state reaction method. The gross structure, surface morphology and microstructure of these nanophosphors have been investigated by X-ray powder diffraction (XRD), scanning electron microscopy (SEM) and transmission/high-resolution transmission electron microscopy (TEM/HRTEM) techniques, respectively. Photoluminescence (PL) and time-resolved photoluminescence (TRPL) spectroscopic methods have been used to explore the striking luminescence properties of the synthesized nanophosphors. The $\mathrm{Gd}_{2}\left(\mathrm{MoO}_{4}\right)_{3}: \mathrm{Eu}^{3+}$ nanophosphor exhibits a hypersensitive red emission $(616 \mathrm{~nm})$ at an excitation wavelength in the range of $250-475 \mathrm{~nm}$ corresponding to a ${ }^{5} \mathrm{D}_{0}-{ }^{7} \mathrm{~F}_{2}$ transition. The $\mathrm{Gd}_{2}\left(\mathrm{MoO}_{4}\right)_{3}: \mathrm{Tb}^{3+}$ and $\mathrm{Gd}_{2}\left(\mathrm{MoO}_{4}\right)_{3}: \mathrm{Tm}^{3+}$ nanophosphors demonstrate a strong green emission at $541 \mathrm{~nm}$ and a deep blue emission at $453 \mathrm{~nm}$ upon an excitation wavelength of $378 \mathrm{~nm}$ and $266 \mathrm{~nm}$, respectively. Moreover, the upconversion characteristic of the $\mathrm{Gd}_{2}\left(\mathrm{MoO}_{4}\right)_{3}: \mathrm{Er}^{3+} / \mathrm{Yb}^{3+}$ nanophosphor exhibits strong green emission at $545 \mathrm{~nm}$ and red emission at $657 \mathrm{~nm}$ corresponding to ${ }^{4} \mathrm{~S}_{3 / 2}-{ }^{4} \mathrm{I}_{15 / 2}$ and ${ }^{4} \mathrm{~F}_{9 / 2}-{ }^{4} \mathrm{I}_{15 / 2}$ transitions respectively. Furthermore, the $\mathrm{Gd}_{2}\left(\mathrm{MoO}_{4}\right)_{3}: \mathrm{Er}^{3+} / \mathrm{Yb}^{3+}$ upconversion nanophosphor emits in the NIR spectrum region at $994 \mathrm{~nm}$ upon a $980 \mathrm{~nm}$ excitation wavelength. Hence, the obtained PL emission results with a lifetime in milliseconds reveal that these nanophosphors could be futuristic promising broad spectral converter phosphors which may possibly integrate with the next-generation Si-solar cell to enhance the efficiency of the cell.
\end{abstract}

\section{Introduction}

Energy is directly related to the currency of any country. There is no doubt that it is always in huge demand, but unluckily, it is always in short supply which is insufficient to match the unparalleled population explosion and our changing comfort lifestyle. Undeniably, we are facing an energy crisis and it has become the most important commodity. Energy consumption will have almost doubled by 2050 compared to the energy consumption in 2001., ${ }^{1,2}$ Consequently, renewable energy sources that can provide sufficient energy to meet the worldwide energy demand have attained huge attention. ${ }^{1-5}$ Sunlight is the most important renewable source of energy which can be directly converted into heat and electricity. Moreover, sunlight is a plentiful source of energy; available almost everywhere in

${ }^{a}$ CSIR - National Physical Laboratory, Dr K S Krishnan Road, New Delhi, 110012, India. E-mail: bipinbhu@yahoo.com; Fax:+91-11-45609310; Tel: +91-11-45609385 ${ }^{b}$ Academy of Scientific and Innovative Research (AcSIR), CSIR - National Physical Laboratory, New Delhi-110012, India

$\dagger$ Electronic supplementary information (ESI) available. See DOI: 10.1039/c4ra15383a the world without any cost. ${ }^{5}$ The photovoltaic cells which convert sunlight directly into electricity are the most prominent source of renewable energy. However, photovoltaic cells are only contributing a limited portion of the energy demand. Therefore, over the past few decades, significant effort has been directed to the development of efficient photovoltaic cells. Still, the efficient and economic cost conversion of sunlight into electricity remains a challenging task. ${ }^{6-8}$ Commercial availability and the economic approach of crystalline and polycrystalline solar cells have been dominating the photovoltaic market to date., ${ }^{\mathbf{9} 10}$ Therefore, an immense amount of research has been devoted to the development of efficient and low cost crystalline and polycrystalline solar cells in the past few decades.

A major drawback of Si-solar cells is that they don't utilize the full solar spectrum when sunlight falls on their surface which limits the energy conversion efficiency. It is well established that the solar spectrum has photons ranging from 250-2500 nm (ultraviolet to infrared) at air mass 1.5 global (AM 1.5G). But, photovoltaic cells only utilize a small portion of the solar spectrum which is attributed only to photons that match the band gap of the material. ${ }^{11}$ In general; there are two kinds of loss in solar cells which limit their efficiency. One is 
that the photons with an energy higher than the band gap (UV radiations) are not efficiently used; the excess energy of the photons is dissipated in the form of heat. Secondly, the photons with low energy (IR radiation) are not absorbed by solar cells and these are transmitted. It is observed that the $70 \%$ loss in solar cells is related to these losses, known as spectral mismatch. One of the promising ways to address this issue is by using downshift (DS) or upconversion (UC) materials as a spectral converter to minimise these losses (thermalisation and non-absorbed losses). A downshift material can absorb the photons with high energy and emit photons that have a lower energy in the visible spectrum region which are subsequently absorbed by the solar cell without any heat dissipation. Upconversion materials absorb two photons that have an energy less than that of the band gap of the solar cell and are converted into a utilized photon (having energy in the visible spectrum region) which is absorbed by the solar cell. This approach to minimising the thermalisation and non-absorbed losses by applying a luminescent layer on the solar cell is termed as third generation solar conversion. ${ }^{5}$ Although there are many materials that have been proposed as luminescence concentrators for the enhancement of solar cell efficiency, lanthanide doped materials are the most suitable materials for solar spectral converters due to their electron rich energy level structure which offers a superficial photon management. Therefore, significant effort has been dedicated to the enhancement of the efficiency of solar cells via modification of the solar spectrum using trivalent lanthanide doped materials. ${ }^{\mathbf{1 2 - 2 3}}$

Among the various trivalent lanthanide ions $\left(\mathrm{Ln}^{3+}\right)$, materials doped with $\mathrm{Eu}^{3+} / \mathrm{Er}^{3+}$ ions (downshift/upconversion phosphors) have gained more inquisitiveness as spectral converters. These materials can emit photons in the visible spectrum which are useful in solar cell applications to create electron-hole pairs. Moreover, host lattices containing d-block transition elements (like tungstate and molybdate) have an advantage over other host lattices because the excitation band is broad due to the charge transfer (CT) in the O-Mo or O-W bond occurring in the UV region, which is sufficiently transferred to the trivalent lanthanide ion. ${ }^{24}$ Furthermore, the $\mathrm{Gd}_{2}\left(\mathrm{MoO}_{4}\right)_{3}$ host matrix possesses beneficial properties such as a high refractive index, high thermal stability, low toxicity and high photochemical stability.

In the present investigation, we have synthesized $\mathrm{Gd}_{2}$ $\left(\mathrm{MoO}_{4}\right)_{3}: \mathrm{Re}^{3+}\left(\mathrm{Re}^{3+}=\mathrm{Eu}^{3+}, \mathrm{Tb}^{3+}, \mathrm{Tm}^{3+}\right.$ and $\left.\mathrm{Er}^{3+} / \mathrm{Yb}^{3+}\right)$ nanophosphors for a proposed solar cell application where these nanophosphors act as a spectral converter nanophosphor. These nanophosphors have the capability to absorb light in a broad range from UV to IR and can emit red, green and blue emission in the visible and NIR regions. The $\mathrm{Gd}_{2}\left(\mathrm{MoO}_{4}\right)_{3}: \mathrm{Eu}^{3+}$ downshift nanophosphor demonstrates a photoluminescence emission peak at $616 \mathrm{~nm}$ (hypersensitive red emission) upon broad excitation ranging from $250-475 \mathrm{~nm}$. Moreover, other two downshift nanophosphors $\mathrm{Gd}_{2}\left(\mathrm{MoO}_{4}\right)_{3}: \mathrm{Tb}^{3+}$ and $\mathrm{Gd}_{2}\left(\mathrm{MoO}_{4}\right)_{3}:-$ $\mathrm{Tm}^{3+}$ exhibit the emission peaks at $541 \mathrm{~nm}$ (strong green) and $453 \mathrm{~nm}$ (deep blue) respectively. Furthermore, the $\mathrm{Gd}_{2}$ $\left(\mathrm{MoO}_{4}\right)_{3}: \mathrm{Er}^{3+} / \mathrm{Yb}^{3+}$ upconversion nanophosphor shows strong green emission at $545 \mathrm{~nm}$ and red emission at $657 \mathrm{~nm}$.
Additionally, the $\mathrm{Gd}_{2}\left(\mathrm{MoO}_{4}\right)_{3}: \mathrm{Er}^{3+} / \mathrm{Yb}^{3+}$ upconversion nanophosphor exhibits emission at $994 \mathrm{~nm}$ (NIR region) upon a $980 \mathrm{~nm}$ excitation wavelength, which is rarely reported in the literature. ${ }^{25,26}$ Thus, $\mathrm{Gd}_{2}\left(\mathrm{MoO}_{4}\right)_{3}: \mathrm{Re}^{3+}\left(\mathrm{Re}^{3+}, \mathrm{Eu}^{3+}, \mathrm{Tb}^{3+}, \mathrm{Tm}^{3+}\right.$ and $\left.\mathrm{Er}^{3+} / \mathrm{Yb}^{3+}\right)$ nanophosphors could be efficiently used as spectral converters, which can absorb light in the 250-475 $\mathrm{nm} / \mathrm{NIR}$ spectrum region and emit in the visible and NIR region which is highly desirable for the modification of the Si-solar cell spectrum. Hence, the obtained results provide a new podium of $\mathrm{Gd}_{2}\left(\mathrm{MoO}_{4}\right)_{3}: \mathrm{Re}^{3+}\left(\mathrm{Re}^{3+}, \mathrm{Eu}^{3+}, \mathrm{Tb}^{3+}, \mathrm{Tm}^{3+}\right.$ and $\left.\mathrm{Er}^{3+} / \mathrm{Yb}^{3+}\right)$ nanophosphors to examine their interesting photoluminescence properties in detail for a proposed Si-solar cell application.

\section{Experimental}

\subsection{Materials}

The precursors; $\mathrm{Y}_{2} \mathrm{O}_{3}$ (99.99\%), $\quad \mathrm{Eu}_{2} \mathrm{O}_{3}$ (99.99\%), $\quad \mathrm{Tm}_{2} \mathrm{O}_{3}$ (99.99\%), $\mathrm{Tb}_{4} \mathrm{O}_{7}(99.99 \%), \quad \mathrm{Er}\left(\mathrm{NO}_{3}\right)_{3} \cdot 5 \mathrm{H}_{2} \mathrm{O}$ (99.99\%), $\mathrm{Yb}_{2} \mathrm{O}_{3}$ $(99.99 \%)$ and $\left(\mathrm{NH}_{4}\right)_{6} \mathrm{Mo}_{7} \mathrm{O}_{24} \cdot 4 \mathrm{H}_{2} \mathrm{O}$ (AR grade, 99\%) were purchased from Sigma-Aldrich. All reagents were of analytical (AR) grade and used as received without further purification.

\subsection{Synthesis of $\mathrm{Gd}_{2}\left(\mathrm{MoO}_{4}\right)_{3}: \mathrm{Re}^{3+}\left(\mathrm{Re}^{3+}, \mathrm{Eu}^{3+}, \mathrm{Tb}^{3+}, \mathrm{Tm}^{3+}\right.$ and $\left.\mathrm{Er}^{3+} / \mathrm{Yb}^{3+}\right)$ nanophosphors}

A facile solid state reaction was used for the synthesis of $\mathrm{Gd}_{2}$ $\left(\mathrm{MoO}_{4}\right)_{3}: \mathrm{Re}^{3+}\left(\mathrm{Re}^{3+}, \mathrm{Eu}^{3+}, \mathrm{Tb}^{3+}, \mathrm{Tm}^{3+}\right.$ and $\left.\mathrm{Er}^{3+} / \mathrm{Yb}^{3+}\right)$ which can be easily scaled-up for large quantities. In order to optimize the concentration and temperature, first we synthesized the red emitting $\mathrm{Gd}_{2-x}\left(\mathrm{MoO}_{4}\right)_{3}: \mathrm{Eu}_{x}{ }^{3+}(x=0.1$ to 0.5$)$ nanophosphor using a solid state reaction method. According to the stoichiometric ratio, the starting materials $\mathrm{Gd}_{2} \mathrm{O}_{3}, \mathrm{Eu}_{2} \mathrm{O}_{3}$, and $\left(\mathrm{NH}_{4}\right)_{6}$ $\mathrm{Mo}_{7} \mathrm{O}_{24} \cdot 4 \mathrm{H}_{2} \mathrm{O}$ were taken. After precise weighing of these materials, the materials were appropriately crushed in an agate mortar for homogeneous mixing. The homogeneous mixture was kept in an alumina crucible and heated in a box furnace at a temperature of $1000{ }^{\circ} \mathrm{C}$ for $3 \mathrm{~h}$. The doping concentration of $\mathrm{Eu}^{3+}$ was varied ( $x=0.1$ to 0.5 ) in order to attain the optimum dopant concentration for the strongest red emission and it was observed that $x=0.2$ is the optimum concentration. Furthermore, in order to compare the luminescence intensity with sintering temperature, the $\mathrm{Gd}_{1.8}\left(\mathrm{MoO}_{4}\right)_{3}: \mathrm{Eu}_{0.2}{ }^{3+}$ phosphor was heated at $800{ }^{\circ} \mathrm{C}, 900{ }^{\circ} \mathrm{C}, 1000{ }^{\circ} \mathrm{C}$ and $1100{ }^{\circ} \mathrm{C}$. The green and blue nanophosphors were synthesized by doping with different rare-earth ions $\left(\mathrm{Tb}^{3+}\right.$ and $\left.\mathrm{Tm}^{3+}\right)$. The nanophosphor was doped with $\mathrm{Tb}^{3+}$ ions were doped to achieve the green emission and $\mathrm{Tm}^{3+}$ ions for blue emission. Similarly, the $\mathrm{Gd}_{2}\left(\mathrm{MoO}_{4}\right)_{3}: \mathrm{Er}^{3+} /$ $\mathrm{Yb}^{3+}\left(\mathrm{Er}^{3+}=5 \mathrm{~mol} \%\right.$ and $\left.\mathrm{Yb}^{3+}=10 \mathrm{~mol} \%\right)$ upconversion nanophosphor were also synthesized by a solid state reaction method keeping the same conditions as for the downshift nanophosphors. Using this method, the yield of the materials was more than $90 \%$ in all cases (downshift and upconversion nanophosphors) with a high degree of homogeneity throughout the mass. The versatility of this method is such that one could easily synthesize large quantities of homogeneous rare earth doped nanophosphors with a narrow size distribution. 


\subsection{Characterization}

The crystal structure was investigated using X-ray powder diffraction (XRD) with a Bruker AXS D8 Advance X-ray diffractometer, using $\mathrm{Cu} \mathrm{K} \alpha_{1}$ radiation $(\lambda=1.5406 \AA)$. The surface morphology was studied using Carl ZEISS EVOR-18 equipment at a $10 \mathrm{kV}$ operating voltage. Transmission electron microscopy (TEM) and high-resolution transmission electron microscopy (HRTEM) micrographs were recorded using a Tecnai G2 S-Twin transmission electron microscope with a field emission gun operating at $300 \mathrm{kV}$. An Edinburgh spectrometer was used for photoluminescence (PL) and time-resolved photoluminescence (TRPL) spectroscopy, where a xenon lamp acted as the source of excitation. To estimate the absolute luminescence quantum efficiency of the QC phosphors, an integrating sphere equipped with an Edinburgh spectrometer (model F900) instrument was used, and then the integrated fractions of luminous flux and radiant flux were measured using the standard method; quantum efficiency was evaluated. The NIR PL emission and PL mapping of the nanophosphors was performed using a WITech alpha 300R+ confocal PL microscope system, where 375 and $980 \mathrm{~nm}$ diode lasers act as source of excitations.

\section{Results and discussion}

A facile solid state reaction method has been used to synthesize $\mathrm{Gd}_{2}\left(\mathrm{MoO}_{4}\right)_{3}: \mathrm{Re}^{3+}\left(\mathrm{Re}^{3+}, \mathrm{Eu}^{3+}, \mathrm{Tb}^{3+}, \mathrm{Tm}^{3+}\right.$ and $\left.\mathrm{Er}^{3+} / \mathrm{Yb}^{3+}\right)$. The $\mathrm{X}$-ray diffraction (XRD) technique has been carried out to investigate the gross structure and phase purity of the nanophosphors. The XRD pattern of the $\mathrm{Gd}_{1.8}\left(\mathrm{MoO}_{4}\right)_{3}: \mathrm{Eu}_{0.2}{ }^{3+}$ downshift nanophosphor is illustrated in Fig. 1(a). The XRD result reveals that the nanophosphor has an orthorhombic crystalline structure with space group $\mathrm{Pba2}$. The estimated lattice parameters for the $\mathrm{Gd}_{1.8}\left(\mathrm{MoO}_{4}\right)_{3}: \mathrm{Eu}_{0.2}{ }^{3+}$ nanophosphor are $a=(10.1631 \pm 0.0023) \AA, b=(10.1132 \pm 0.0021) \AA$ and $c=(10.74 \pm 0.0027) \AA$, which are comparable with the existing $\mathrm{Gd}_{2}\left(\mathrm{MoO}_{4}\right)_{3}$ host (JCPDS card no. 20-0408). The estimated crystallite size of the $\mathrm{Gd}_{1.8}\left(\mathrm{MoO}_{4}\right)_{3}: \mathrm{Eu}_{0.2}{ }^{3+}$ nanophosphor is $\sim 28 \mathrm{~nm}$ using the standard Scherrer formula. The XRD patterns of $\mathrm{Gd}_{2-x}\left(\mathrm{MoO}_{4}\right)_{3}: \mathrm{Eu}_{x}{ }^{3+}$ downshift nanophosphors for different concentrations ( $x=0.1$ to 0.5 ) are demonstrated in Fig. S1 (see ESI $\dagger$ ). The lattice parameters for all variants of the $\mathrm{Gd}_{2-x^{-}}$ $\left(\mathrm{MoO}_{4}\right)_{3}: \mathrm{Eu}_{x}{ }^{3+}$ nanophosphors $(x=0.1$ to 0.5$)$ were calculated from the observed $d$-values through a least square fitting
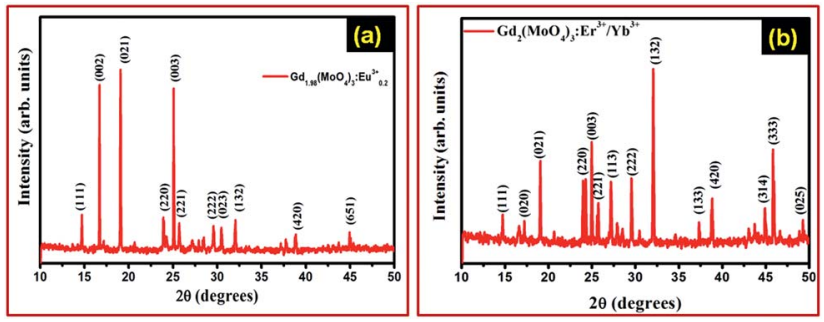

Fig. 1 The XRD patterns of the (a) $\mathrm{Gd}_{1.8}\left(\mathrm{MoO}_{4}\right)_{3}: \mathrm{Eu}_{0.2}{ }^{3+}$ downshift nanophosphor and (b) $\mathrm{Gd}_{2}\left(\mathrm{MoO}_{4}\right)_{3}: \mathrm{Er}^{3+} / \mathrm{Yb}^{3+}$ upconversion nanophosphor. method using computer program based unit cell refinement software. ${ }^{27}$ The unit cell volume was estimated from these parameters and is exhibited in Table S1. $\dagger$ It was observed that the unit cell volume increased with $\mathrm{Eu}^{3+}$-doping concentration up to a value of 0.2 and then after this it started to decrease. The decrease in the unit cell volume decreases the inter-ionic distance between the $\mathrm{Eu}^{3+}$ ions which leads to an increase in non-radiative emission which decreases the luminescence intensity. Furthermore, the obtained results for the different concentrations $(x=0.1$ to 0.5$)$ of $\mathrm{Gd}_{2-x}\left(\mathrm{MoO}_{4}\right)_{3}: \mathrm{Eu}_{x}{ }^{3+}$ nanophosphors, with their unit cell parameters, are consistent with the obtained PL emission results. Therefore, the emission intensity is maximum for doping concentration $x=0.2$. Fig. $\mathrm{S} 2 \uparrow$ exhibits the XRD patterns of the $\mathrm{Gd}_{1.8}\left(\mathrm{MoO}_{4}\right)_{3}: \mathrm{Eu}_{0.2}{ }^{3+}$ downshift nanophosphor at different sintering temperatures $\left(800{ }^{\circ} \mathrm{C}\right.$, $900{ }^{\circ} \mathrm{C}, 1000{ }^{\circ} \mathrm{C}$ and $\left.1100{ }^{\circ} \mathrm{C}\right) .{ }^{28}$ The obtained XRD patterns of the $\mathrm{Gd}_{1.8}\left(\mathrm{MoO}_{4}\right)_{3}: \mathrm{Eu}_{0.2}{ }^{3+}$ nanophosphor at different sintering temperatures reveals that the relative peak intensity of $\mathrm{Gd}_{1.8^{-}}$ $\left(\mathrm{MoO}_{4}\right)_{3}: \mathrm{Eu}_{0.2}{ }^{3+}$ increases when the sintering temperature increases from 800 to $1000{ }^{\circ} \mathrm{C}$. Above $1000{ }^{\circ} \mathrm{C}$, the secondary phases start to appear, and as a result it affects the PL intensity of the $\mathrm{Gd}_{1.8}\left(\mathrm{MoO}_{4}\right)_{3}: \mathrm{Eu}_{0.2}{ }^{3+}$ nanophosphor, which is further discussed in detail in the PL section. Fig. 1(b) demonstrates the XRD pattern of the $\mathrm{Gd}_{2}\left(\mathrm{MoO}_{4}\right)_{3}: \mathrm{Er}^{3+} / \mathrm{Yb}^{3+}$ upconversion nanophosphor. The XRD patterns of the $\mathrm{Gd}_{1.8}\left(\mathrm{MoO}_{4}\right)_{3}: \mathrm{Tb}_{0.2}{ }^{3+}$ and $\mathrm{Gd}_{1.8}\left(\mathrm{MoO}_{4}\right)_{3}: \mathrm{Tm}_{0.2}{ }^{3+}$ downshift nanophosphors are illustrated in Fig. S3 (see ESI†).

Scanning electron microscopy (SEM) has been used to explore the surface morphology of the synthesized nanophosphors. Fig. 2(a) exhibits the SEM image of the $\mathrm{Gd}_{1.8^{-}}$ $\left(\mathrm{MoO}_{4}\right)_{3}: \mathrm{Eu}_{0.2}{ }^{3+}$ downshift nanophosphor. To gain more information about the microstructure of the $\mathrm{Gd}_{1.8}\left(\mathrm{MoO}_{4}\right)_{3}: \mathrm{Eu}_{0.2}{ }^{3+}$ nanophosphor, transmission electron microscopy (TEM) and
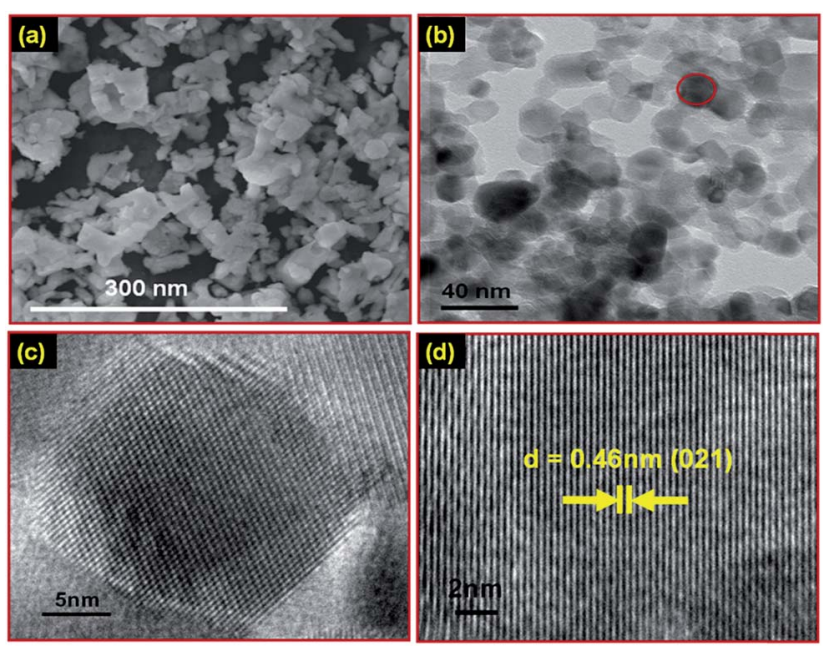

Fig. 2 (a) SEM image of the $\mathrm{Gd}_{1.8}\left(\mathrm{MoO}_{4}\right)_{3}: \mathrm{Eu}_{0.2^{3+}}$ downshift nanophosphor, (b) TEM image of the $\mathrm{Gd}_{1.8}\left(\mathrm{MoO}_{4}\right)_{3}: \mathrm{Eu}_{0.2}{ }^{3+}$ downshift nanophosphor, (c) a typical HRTEM image of a selected individual particle which is marked by the red circle in (b), and (d) HRTEM image of the $\mathrm{Gd}_{1.8}\left(\mathrm{MoO}_{4}\right)_{3}: \mathrm{Eu}_{0.2^{3+}}$ downshift nanophosphor which exhibits the clear lattice fringes without any distortion. 
high-resolution transmission electron microscopy (HRTEM) was performed. The TEM image of the $\mathrm{Gd}_{1.8}\left(\mathrm{MoO}_{4}\right)_{3}: \mathrm{Eu}_{0.2}{ }^{3+}$ downshift nanophosphor is shown in Fig. 2(b). The TEM image shows that the average particle size of the nanophosphor is $\sim 24$ $\mathrm{nm}$. The size distribution histogram of the $\mathrm{Gd}_{1.8}\left(\mathrm{MoO}_{4}\right)_{3}: \mathrm{Eu}_{0.2}{ }^{3+}$ downshift nanophosphor is shown in Fig. S4 (see ESI†). The HRTEM image of a selected individual nanoparticle (marked in Fig. 2(b)) is shown in Fig. 2(c). Fig. 2(d) represents that the HRTEM image of the nanophosphor exhibits the clear lattice fringes without any distortion, which confirms that the nanophosphor has good crystal quality. The estimated $d$-spacing is measured to be $\sim 0.46 \mathrm{~nm}$ from Fig. 2(d), which is analogous to the $d$-spacing corresponding to the (021) plane (JCPDS card no. 20-0408). Moreover, the selected area electron diffraction (SAED) pattern of the $\mathrm{Gd}_{1.8}\left(\mathrm{MoO}_{4}\right)_{3}: \mathrm{Eu}_{0.2}{ }^{3+}$ nanophosphor was also obtained. Fig. S5 (see ESI $\dagger$ ) demonstrates the SAED pattern of $\mathrm{Gd}_{1.8}\left(\mathrm{MoO}_{4}\right)_{3}: \mathrm{Eu}_{0.2}{ }^{3+}$ which clearly exhibits that the nanophosphor is highly crystalline. Furthermore, energy dispersive $\mathrm{X}$-ray analysis (EDAX) was performed for elemental detection. Fig. S6 (see ESI $\dagger$ ) shows the EDAX spectrum of the $\mathrm{Gd}_{2}$ $\left(\mathrm{MoO}_{4}\right)_{3}: \mathrm{Eu}_{0.2}{ }^{3+}$ downshift nanophosphor which confirms the presence of Gd, Mo, O and Eu. Moreover, the elemental analysis for the upconversion nanophosphor was also performed. The EDAX spectrum of the $\mathrm{Gd}_{2}\left(\mathrm{MoO}_{4}\right)_{3}: \mathrm{Er}^{3+} / \mathrm{Yb}^{3+}$ upconversion nanophosphor is shown in Fig. S7 (see ESI $\dagger$ ) which confirms the presence of Gd, Mo, O, Er and $\mathrm{Yb}$.

Furthermore, PL and TRPL spectroscopy have been carried out to explore the spectroscopic characteristics of the synthesized nanophosphor to examine the feasibility of the nanophosphor for the proposed spectral converter application. The photoluminescence excitation (PLE) spectrum of the $\mathrm{Gd}_{1.8^{-}}$ $\left(\mathrm{MoO}_{4}\right)_{3}: \mathrm{Eu}_{0.2}{ }^{3+}$ downshift nanophosphor is illustrated in
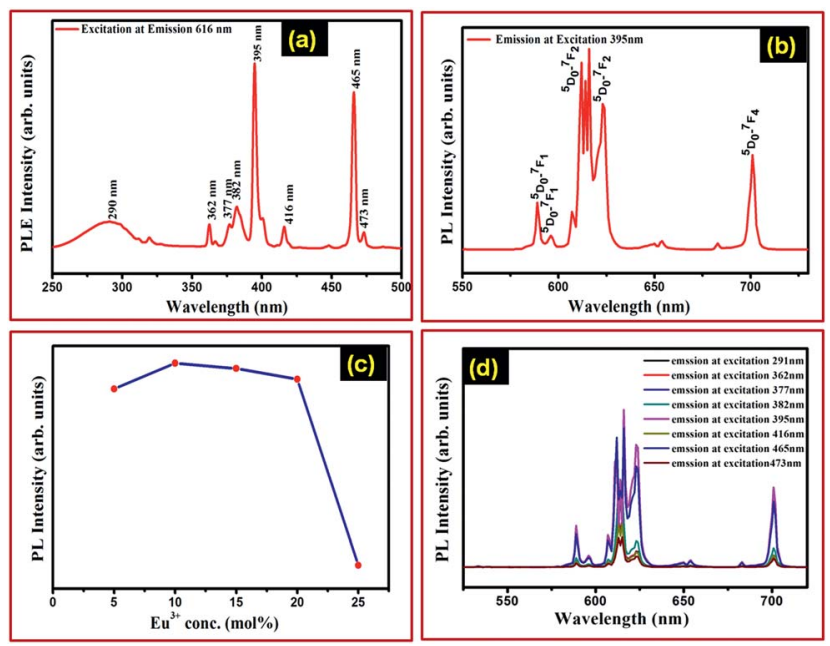

Fig. 3 (a) The excitation spectrum of the $\mathrm{Gd}_{1.8}\left(\mathrm{MoO}_{4}\right)_{3}: \mathrm{Eu}_{0.2}{ }^{3+}$ downshift nanophosphor at emission $616 \mathrm{~nm}$, (b) the PL emission spectrum with quantum efficiency $\sim 84 \%$ of the $\mathrm{Gd}_{1.8}\left(\mathrm{MoO}_{4}\right)_{3}: \mathrm{Eu}_{0.2}{ }^{3+}$ downshift nanophosphor at an excitation wavelength of $395 \mathrm{~nm}$, (c) PL intensity variation with doping concentration of $\mathrm{Eu}^{3+}$ in the $\mathrm{Gd}_{2-x^{-}}$ $\left(\mathrm{MoO}_{4}\right)_{3}: \mathrm{Eu}_{x}{ }^{3+}$ downshift nanophosphor and (d) PL emission spectra of the $\mathrm{Gd}_{1.8}\left(\mathrm{MoO}_{4}\right)_{3}: \mathrm{Eu}_{0.2^{3+}}$ downshift nanophosphor at different excitation wavelengths.
Fig. 3(a). The excitation spectrum has a broad band around $290 \mathrm{~nm}$ and sharp peaks in the range of 350-475 $\mathrm{nm}$. The broad band at $\sim 290 \mathrm{~nm}$ is due to the energy charge transfer between Mo-O. It is well known that a transition metal containing host matrix (like $\mathrm{VO}_{4}{ }^{3-}, \mathrm{NbO}_{4}{ }^{3-}, \mathrm{WO}_{4}{ }^{2-}$ and $\mathrm{MoO}_{4}{ }^{2-}$ group containing host matrices) has an additional advantage over the other host matrices as it can absorb a broad range in the UV spectrum region due to the charge transfer between the electron deficient transition metal ion and electron rich oxygen ion. ${ }^{\mathbf{2 4 , 2 9}}$ Therefore, the energy transfer between the transition metal atom and the oxygen atom is a very important factor to enhance the luminescence properties of inorganic phosphors. The sharp peaks are characteristics of the $\mathrm{f}-\mathrm{f}$ transition within the $4 \mathrm{f}^{6}$ electron shell of the $\mathrm{Eu}^{3+}$ ion in the host lattices. The two strong excitation peaks at $395 \mathrm{~nm}$ and $465 \mathrm{~nm}$ are attributed to the ${ }^{7} \mathrm{~F}_{0}-{ }^{5} \mathrm{~L}_{6}$ and ${ }^{7} \mathrm{~F}_{0^{-}}{ }^{5} \mathrm{D}_{2}$ transitions of the $\mathrm{Eu}^{3+}$ ion, respectively. ${ }^{30}$ Fig. 3(b) depicts the emission spectrum of the $\mathrm{Gd}_{1.8}\left(\mathrm{MoO}_{4}\right)_{3}$ : $\mathrm{Eu}_{0.2}{ }^{3+}$ downshift nanophosphor at an excitation wavelength of $395 \mathrm{~nm}$. The emission spectrum shows hyperfine red emission at $616 \mathrm{~nm}$ with a quantum efficiency of $\sim 84 \%$. The emission peaks at $589 \mathrm{~nm}, 596 \mathrm{~nm}, 616 \mathrm{~nm}, 623 \mathrm{~nm}$ and $701 \mathrm{~nm}$ are attributed to ${ }^{5} \mathrm{D}_{0}-{ }^{7} \mathrm{~F}_{1},{ }^{5} \mathrm{D}_{0}-{ }^{7} \mathrm{~F}_{1},{ }^{5} \mathrm{D}_{0}-{ }^{7} \mathrm{~F}_{2},{ }^{5} \mathrm{D}_{0}-{ }^{7} \mathrm{~F}_{2}$ and ${ }^{5} \mathrm{D}_{0}{ }^{-}{ }^{7} \mathrm{~F}_{4}$ transitions, respectively. The strong red emission of the nanophosphor has been obtained by optimising the doping concentration of $\mathrm{Eu}^{3+}$ ions. Fig. 3(c) reveals the variation in luminescence intensity with the doping concentration of $\mathrm{Eu}^{3+}$ ions. It has been observed that the luminescence intensity increases with an increase in the doping concentration of $\mathrm{Eu}^{3+}$ up to $10 \mathrm{~mol} \%$. However, with a further increase of $\mathrm{Eu}^{3+}$ concentration, the luminescence intensity starts to decrease and it decreases rapidly after $20 \mathrm{~mol} \%$ concentration. The decrease in luminescence intensity with an increase in $\mathrm{Eu}^{3+}$ concentration is due to the decrease in the distance between two $\mathrm{Eu}^{3+}$ ions in the host matrix. This decrease in the distance between the $\mathrm{Eu}^{3+}$ ions reduces the probability of the radiative transitions of the $\mathrm{Eu}^{3+}$ ions due to mutual interaction at the shortened distances between two $\mathrm{Eu}^{3+}$ ions at high doping concentrations which leads to non-radiative emission which decreases luminescence intensity. Therefore, the obtained result suggests that $10 \mathrm{~mol} \%$ is the optimised doping concentration. In addition, the $\mathrm{Gd}_{1.8}\left(\mathrm{MoO}_{4}\right)_{3}: \mathrm{Eu}_{0.2}{ }^{3+}$ nanophosphor has been sintered at different temperatures $\left(800\right.$ to $\left.1100{ }^{\circ} \mathrm{C}\right)$ for optimization of the sintering temperature for luminescence intensity. The variation in luminescence intensity with sintering temperature is shown in Fig. S8 (see ESI $\dagger$ ). It has been observed that $1000{ }^{\circ} \mathrm{C}$ is the optimum temperature having the highest luminescence intensity. Furthermore, the PL emission intensity of the $\mathrm{Gd}_{1.8}\left(\mathrm{MoO}_{4}\right)_{3}: \mathrm{Eu}_{0.2}{ }^{3+}$ downshift nanophosphor decreases at $1100{ }^{\circ} \mathrm{C}$ and above. The decrease in PL emission intensity at $1100{ }^{\circ} \mathrm{C}$ is due to the formation of secondary phases at high temperatures which was earlier observed in the XRD pattern of the $\mathrm{Gd}_{1.8}\left(\mathrm{MoO}_{4}\right)_{3}: \mathrm{Eu}_{0.2}{ }^{3+}$ downshift nanophosphor at $1100{ }^{\circ} \mathrm{C}$. Fig. 3(d) exhibits the emission spectra of the $\mathrm{Gd}_{1.8}\left(\mathrm{MoO}_{4}\right)_{3}$ : $\mathrm{Eu}_{0.2}{ }^{3+}$ downshift nanophosphor at different excitation wavelengths. It shows that a $395 \mathrm{~nm}$ excitation wavelength has the maximum emission intensity which signifies that $395 \mathrm{~nm}$ is the prominent excitation wavelength for a maximum emission 
intensity. The proposed energy level diagram for the $\mathrm{Gd}_{1.8^{-}}$ $\left(\mathrm{MoO}_{4}\right)_{3}: \mathrm{Eu}_{0.2}{ }^{3+}$ downshift nanophosphor has been illustrated in Fig. S9 (see ESI $\dagger$ ) which explicated the downshift mechanism for the luminescence process in the $\mathrm{Gd}_{1.8}\left(\mathrm{MoO}_{4}\right)_{3}: \mathrm{Eu}_{0.2}{ }^{3+}$ nanophosphor.

Moreover, the photoluminescence properties of the $\mathrm{Gd}_{1.8^{-}}$ $\left(\mathrm{MoO}_{4}\right)_{3}: \mathrm{Tb}_{0.2}{ }^{3+}$ and $\mathrm{Gd}_{1.8}\left(\mathrm{MoO}_{4}\right)_{3}: \mathrm{Tm}_{0.2}{ }^{3+}$ downshift nanophosphors have also been carried out to explore the spectroscopic characteristics of the synthesized nanophosphors to examine the feasibility of these nanophosphors with different dopants for possible spectral converter application. Fig. S10 (see ESI $\dagger$ ) exhibits the photoluminescence properties of the $\mathrm{Gd}_{1.8^{-}}$ $\left(\mathrm{MoO}_{4}\right)_{3}: \mathrm{Tb}_{0.2}{ }^{3+}$ and $\mathrm{Gd}_{1.8}\left(\mathrm{MoO}_{4}\right)_{3}: \mathrm{Tm}_{0.2}{ }^{3+}$ downshift nanophosphors. Fig. S10(a) $\dagger$ shows that the emission spectrum of the $\mathrm{Gd}_{1.8}\left(\mathrm{MoO}_{4}\right)_{3}: \mathrm{Tb}_{0.2}{ }^{3+}$ downshift nanophosphor has strong green emission at $541 \mathrm{~nm}$ upon excitation at $378 \mathrm{~nm}$. Fig. S10(b) $\dagger$ shows the excitation spectrum of the $\mathrm{Gd}_{1.8^{-}}$ $\left(\mathrm{MoO}_{4}\right)_{3}: \mathrm{Tb}_{0.2}{ }^{3+}$ downshift nanophosphors at emission of $541 \mathrm{~nm}$. The emission spectrum of the $\mathrm{Gd}_{1.8}\left(\mathrm{MoO}_{4}\right)_{3}: \mathrm{Tm}_{0.2}{ }^{3+}$ downshift nanophosphor is illustrated in Fig. S11(c). $\dagger$ The emission spectrum of the $\mathrm{Gd}_{1.8}\left(\mathrm{MoO}_{4}\right)_{3}: \mathrm{Tm}_{0.2}{ }^{3+}$ downshift nanophosphor shows hypersensitive blue emission at $453 \mathrm{~nm}$ upon excitation at $266 \mathrm{~nm}$. Fig. S10(d) $\uparrow$ shows the excitation spectrum of the $\mathrm{Gd}_{1.8}\left(\mathrm{MoO}_{4}\right)_{3}: \operatorname{Tm}_{0.2}{ }^{3+}$ downshift nanophosphor at emission of $453 \mathrm{~nm}$. The TRPL technique is an imperative and non-destructive tool which has been used to determine the decay lifetime of the nanophosphor. The lifetime data of a nanophosphor is very important and it helps to decide a suitable application for the nanophosphor. Fig. S11(a) (see ESI $\dagger$ ) shows the decay profile of the $\mathrm{Gd}_{1.8}\left(\mathrm{MoO}_{4}\right)_{3}: \mathrm{Eu}_{0.2}{ }^{3+}$ downshift nanophosphor at emission of $616 \mathrm{~nm}$ upon an excitation wavelength of $395 \mathrm{~nm}$ for ${ }^{7} \mathrm{~F}_{0}-{ }^{5} \mathrm{D}_{2}$ transitions of $\mathrm{Eu}^{3+}$ ions. The inset in Fig. S11(a) $\dagger$ exhibits the exponential fitting parameters of the decay profile of the $\mathrm{Gd}_{1.8}\left(\mathrm{MoO}_{4}\right)_{3}: \mathrm{Eu}_{0.2}{ }^{3+}$ downshift nanophosphor. The decay profile has been best fitted to the double exponential function as described in eqn (1): $:^{31}$

$$
I(t)=A_{1} \exp \left(-t / \tau_{1}\right)+A_{2} \exp \left(-t / \tau_{2}\right)
$$

where $\tau_{1}, \tau_{2}, A_{1}$ and $A_{2}$ are the decay lifetimes of the luminescence and weighting parameters, respectively.

The obtained parameters after the double exponential fitting are listed in the inset of Fig. S11(a). $\dagger$ The decay lifetimes of the $\mathrm{Gd}_{1.8}\left(\mathrm{MoO}_{4}\right)_{3}: \mathrm{Eu}_{0.2}{ }^{3+}$ downshift nanophosphor are $\tau_{1} \sim 0.56 \mathrm{~ms}$ and $\tau_{2} \sim 0.81 \mathrm{~ms}$. The average decay lifetime of the $\mathrm{Gd}_{1.8^{-}}$ $\left(\mathrm{MoO}_{4}\right)_{3}: \mathrm{Eu}_{0.2}{ }^{3+}$ nanophosphor is $\tau_{\mathrm{av}} \sim 0.64 \mathrm{~ms}$ which is measured using eqn (2) as described below.

$$
\tau_{\mathrm{av}}=\left(A_{1} \tau_{1}^{2}+A_{2} \tau_{2}^{2}\right) /\left(A_{1} \tau_{1}+A_{2} \tau_{2}\right)
$$

Therefore, the achieved PL and TRPL results suggest that the $\mathrm{Gd}_{1.8}\left(\mathrm{MoO}_{4}\right)_{3}: \mathrm{Re}_{0.2}{ }^{3+}\left(\mathrm{Re}^{3+}=\mathrm{Eu}^{3+}, \mathrm{Tb}^{3+}\right.$ and $\left.\mathrm{Tm}^{3+}\right)$ downshift nanophosphors meets the stringent criteria of Si-solar cells and it is highly suitable for Si-solar cells as well as other display and biological applications. The CIE colour co-ordinates of $\mathrm{Gd}_{1.8^{-}}$ $\left(\mathrm{MoO}_{4}\right)_{3}: \mathrm{Re}_{0.2}{ }^{3+}\left(\mathrm{Re}^{3+}=\mathrm{Eu}^{3+}, \mathrm{Tb}^{3+}\right.$ and $\left.\mathrm{Tm}^{3+}\right)$ are exhibited in Fig. S11(b) (see ESI $\dagger$ ). The symbolic marks A $(x=0.66, y=0.33)$,
$\mathrm{B}(x=0.34, y=0.60)$ and $\mathrm{C}(x=0.14, y=0.11)$ demonstrate the CIE colour co-ordinates for $\mathrm{Gd}_{1.8}\left(\mathrm{MoO}_{4}\right)_{3}: \mathrm{Eu}_{0.2}{ }^{3+}, \mathrm{Gd}_{1.8^{-}}$ $\left(\mathrm{MoO}_{4}\right)_{3}: \mathrm{Tb}_{0.2}{ }^{3+}$ and $\mathrm{Gd}_{1.8}\left(\mathrm{MoO}_{4}\right)_{3}: \mathrm{Tm}_{0.2}{ }^{3+}$ emission, respectively.

In order to explore the upconversion nature of the $\mathrm{Gd}_{2}$ $\left(\mathrm{MoO}_{4}\right)_{3}: \mathrm{Er}^{3+} / \mathrm{Yb}^{3+}$ nanophosphor, we have also performed PL spectroscopy of the synthesized upconversion nanophosphor. Conceptually, upconversion is a process in which the consecutive absorption of two photons of lower energy (IR spectrum region) and emission of a higher energy photon (visible spectrum region) occurs..$^{32}$ Upconversion materials are of particular interest for solar cell application because these materials utilize the IR region of the solar spectrum which is transmitted by solar cells. ${ }^{15,33-38}$ The emission spectra of the $\mathrm{Gd}_{2}\left(\mathrm{MoO}_{4}\right)_{3}: \mathrm{Er}^{3+} / \mathrm{Yb}^{3+}$ upconversion nanophosphor upon excitation at a wavelength of $980 \mathrm{~nm}$ are shown in Fig. 4(a) and (b). Fig. 4(a) exhibits the strong green emission at $545 \mathrm{~nm}$ and red emission at $657 \mathrm{~nm}$, which are attributed to ${ }^{4} \mathrm{~S}_{3 / 2}-{ }^{4} \mathrm{I}_{15 / 2}$ and ${ }^{4} \mathrm{~F}_{9 / 2}{ }^{4} \mathrm{I}_{15 / 2}$ transitions, respectively. Additionally, the emission spectrum also demonstrates a weak emission centred at a wavelength of $525 \mathrm{~nm}$ which is attributed to the ${ }^{2} \mathrm{H}_{11 / 2}-{ }^{4} \mathrm{I}_{15 / 2}$ transition. Moreover, the $\mathrm{Gd}_{2}\left(\mathrm{MoO}_{4}\right)_{3}: \mathrm{Er}^{3+} / \mathrm{Yb}^{3+}$ upconversion nanophosphor has a strong emission at $994 \mathrm{~nm}$, as shown in Fig. 4(b), which is rarely reported in the literature to the best of our knowledge. This emission is also efficiently contributing to the enhancement of the solar cell efficiency because of the fact that the energy of these photons is very near to that of the band gap of the solar cell. The CIE colour co-ordinates of the $\mathrm{Gd}_{2}\left(\mathrm{MoO}_{4}\right)_{3}: \mathrm{Er}^{3+} / \mathrm{Yb}^{3+}$ nanophosphor corresponding to upconversion emission at $980 \mathrm{~nm}$ excitation wavelength are exhibited in Fig. 4(c) with values $x=0.29$ and $y=0.68$.

Fig. 4(d) is a schematic diagram for the upconversion process in the $\mathrm{Gd}_{2}\left(\mathrm{MoO}_{4}\right)_{3}: \mathrm{Er}^{3+} / \mathrm{Yb}^{3+}$ nanophosphor. In the
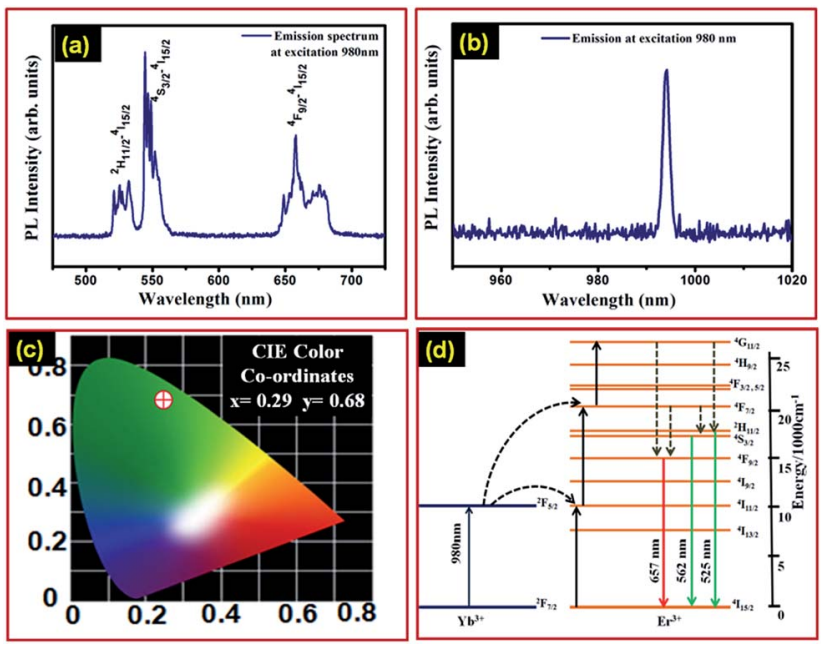

Fig. 4 ( $a$ and b) The emission spectra (range 450-750 and 900-1020 nm) of the $\mathrm{Gd}_{2}\left(\mathrm{MoO}_{4}\right)_{3}: \mathrm{Er}^{3+} / \mathrm{Yb}^{3+}$ upconversion nanophosphor at excitation of wavelength $980 \mathrm{~nm}$, (c) the CIE colour coordinates of the $\mathrm{Gd}_{2}\left(\mathrm{MoO}_{4}\right)_{3}: \mathrm{Er}^{+} / \mathrm{Yb}^{3+}$ upconversion nanophosphor which exhibits a green emission and (d) the schematic for the proposed upconversion process in the $\mathrm{Gd}_{2}\left(\mathrm{MoO}_{4}\right)_{3}: \mathrm{Er}^{3+} / \mathrm{Yb}^{3+}$ nanophosphor. 
$\mathrm{Gd}_{2}\left(\mathrm{MoO}_{4}\right)_{3}: \mathrm{Er}^{3+} / \mathrm{Yb}^{3+}$ upconversion nanophosphor, the $\mathrm{Yb}^{3+}$ ion acts as a sensitizer and $\mathrm{Er}^{3+}$ is used as the dopant, which provides the emission. $\mathrm{Yb}^{3+}$ is used for the sensitizer because it can absorb broadly in the NIR region as compared to the $\mathrm{Er}^{3+}$ ion. In the case of upconversion, both $\mathrm{Yb}^{3+}$ and $\mathrm{Er}^{3+}$ ions absorbed incident photons of $980 \mathrm{~nm}$ in wavelength.

However, absorption across the ${ }^{2} \mathrm{~F}_{7 / 2}{ }^{2} \mathrm{~F}_{5 / 2}$ transition in $\mathrm{Yb}^{3+}$ ions involves more photons compared to absorption across the ${ }^{4} \mathrm{I}_{15 / 2}-{ }^{4} \mathrm{I}_{11 / 2}$ transition in the case of $\mathrm{Er}^{3+}$ ions. Therefore, $\mathrm{Yb}^{3+}$ ions absorb most of the incident photons. Furthermore, $\mathrm{Yb}^{3+}$ ions can also sufficiently transfer energy to $\mathrm{Er}^{3+}$ ions because the energy of the ${ }^{2} \mathrm{~F}_{5 / 2}$ level in $\mathrm{Yb}^{3+}$ ions is similar to the energy of the ${ }^{4} \mathrm{I}_{11 / 2}$ level of the $\mathrm{Er}^{3+}$ ions. ${ }^{30}$ The excited $\mathrm{Yb}^{3+}$ ions relax to the ground state and transfer energy to neighbouring $\mathrm{Er}^{3+}$ ions. Therefore, the excited $\mathrm{Er}^{3+}$ ions absorb energy from $\mathrm{Yb}^{3+}$ ions and are promoted to a higher excitation state which increases the population in a higher energy state. Otherwise, $\mathrm{Er}^{3+}$ ions can absorb two low energy photons simultaneously which drives $\mathrm{Er}^{3+}$ ions to a higher energy states. The relaxation of the excited $\mathrm{Er}^{3+}$ ions to the ground state produces upconversion and emits a strong green coloured emission corresponding to a ${ }^{4} \mathrm{~S}_{3 / 2}{ }^{4} \mathrm{I}_{15 / 2}$ transition whereas red emission is seen in the case of a ${ }^{4} \mathrm{~F}_{9 / 2}-{ }^{4} \mathrm{I}_{15 / 2}$ transition.

Furthermore, the PL emissions of the $\mathrm{Gd}_{2}\left(\mathrm{MO}_{4}\right)_{3}: \mathrm{Eu}^{3+}$ and $\mathrm{Gd}_{2}\left(\mathrm{MoO}_{4}\right)_{3}: \mathrm{Er}^{3+} / \mathrm{Yb}^{3+}$ nanophosphors are also comparable with other similar host systems with the same dopants $\left(\mathrm{GdPO}_{4}: \mathrm{Eu}^{3+}\right.$, $\mathrm{GdBO}_{3}: \mathrm{Eu}^{3+}, \mathrm{GdPO}_{4}: \mathrm{Er}^{3+} / \mathrm{Yb}^{3+}$ and $\mathrm{GdBO}_{3}: \mathrm{Er}^{3+} / \mathrm{Yb}^{3+}$ ). Fig. S12(a) (see ESI $\dagger$ ) shows the emission spectra of $\mathrm{Gd}_{2}\left(\mathrm{MO}_{4}\right)_{3}: \mathrm{Eu}^{3+}$, $\mathrm{GdPO}_{4}: \mathrm{Eu}^{3+}$ and $\mathrm{GdBO}_{3}: \mathrm{Eu}^{3+}$ downshift nanophosphors under an excitation wavelength of $395 \mathrm{~nm}$. Fig. S12(b) (see ESI $\dagger$ ) exhibits the emission spectra of $\mathrm{Gd}_{2}\left(\mathrm{MoO}_{4}\right)_{3}: \mathrm{Er}^{3+} / \mathrm{Yb}^{3+}$, $\mathrm{GdPO}_{4}: \mathrm{Er}^{3+} / \mathrm{Yb}^{3+}$ and $\mathrm{GdBO}_{3}: \mathrm{Er}^{3+} / \mathrm{Yb}^{3+}$ upconversion nanophosphors at an excitation wavelength of $980 \mathrm{~nm}$. The obtained results shown in Fig. $\mathrm{S} 12 \uparrow$ reveal that a $\mathrm{Gd}_{2}\left(\mathrm{MO}_{4}\right)_{3}$ host lattice based nanophosphor has high emission in both downshift as well as upconversion forms which may be due to an efficient energy transfer from the host lattice to the activator compared to other similar host lattice systems.

Moreover, PL mapping of downshift as well as upconversion nanophosphors was performed for confirmation of uniform emission from the nanophosphors. Fig. 5(a) exhibits the optical image of the $\mathrm{Gd}_{1.8}\left(\mathrm{MoO}_{4}\right)_{3}: \mathrm{Eu}_{0.2}{ }^{3+}$ downshift nanophosphor on a glass slide. The PL map of the red marked area in optical image Fig. 5(a) under an excitation wavelength of $375 \mathrm{~nm}$ is shown in Fig. 5(b). Fig. 5(b) clearly shows that the nanophosphor has uniform PL emission. The optical image of the $\mathrm{Gd}_{2}\left(\mathrm{MoO}_{4}\right)_{3}: \mathrm{Er}^{3+} / \mathrm{Yb}^{3+}$ upconversion nanophosphor is illustrated in Fig. 5(c). Fig. 5(d) reveals the PL mapping image of the $\mathrm{Gd}_{2}\left(\mathrm{MoO}_{4}\right)_{3}: \mathrm{Er}^{3+} / \mathrm{Yb}^{3+}$ upconversion nanophosphor of the marked region in Fig. 5(c) under an excitation wavelength of 980 $\mathrm{nm}$. The obtained result reveals that the photoluminescence emission intensity is uniformly distributed in both $\mathrm{Gd}_{1.8^{-}}$ $\left(\mathrm{MoO}_{4}\right)_{3}: \mathrm{Eu}_{0.2}{ }^{3+}$ downshift and $\mathrm{Gd}_{2}\left(\mathrm{MoO}_{4}\right)_{3}: \mathrm{Er}^{3+} / \mathrm{Yb}^{3+}$ upconversion nanophosphors.

The $\mathrm{Gd}_{2}\left(\mathrm{MoO}_{4}\right)_{3}: \mathrm{Eu}^{3+}$ downshift nanophosphor can absorb photons of high energy in the range of 250-475 $\mathrm{nm}$ and give a strong red emission. The Si-solar cell cannot utilise photons
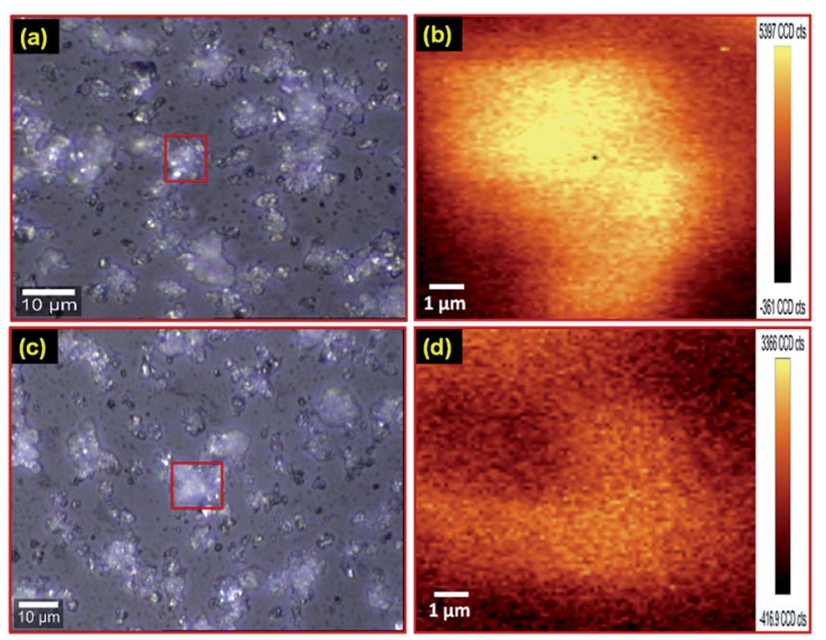

Fig. 5 (a) Optical image of the $\mathrm{Gd}_{1.8}\left(\mathrm{MoO}_{4}\right)_{3}: \mathrm{Eu}_{0.2^{3+}}$ downshift nanophosphor on a glass slide, (b) the PL mapping image of the selected region (marked by red square in (a)) of the $\mathrm{Gd}_{1.8}\left(\mathrm{MoO}_{4}\right)_{3}$ : $\mathrm{Eu}_{0.2^{3+}}$ downshift nanophosphor excited at an excitation wavelength of $375 \mathrm{~nm}$. (c) Optical image of the $\mathrm{Gd}_{2}\left(\mathrm{MoO}_{4}\right)_{3}: \mathrm{Er}^{3+} / \mathrm{Yb}^{3+}$ upconversion nanophosphor on a glass slide, (d) the PL mapping image of the selected region (marked by red square in (c)) of the $\mathrm{Gd}_{2}\left(\mathrm{MoO}_{4}\right)_{3}$ : $\mathrm{Er}^{3+} / \mathrm{Yb}^{3+}$ upconversion nanophosphor excited at an excitation wavelength of $980 \mathrm{~nm}$.

falling in this range of energy because of thermal losses. The $\mathrm{Gd}_{2}\left(\mathrm{MoO}_{4}\right)_{3}: \mathrm{Eu}^{3+}$ downshift nanophosphor can easily absorb the photons falling in this region and emits in the visible region
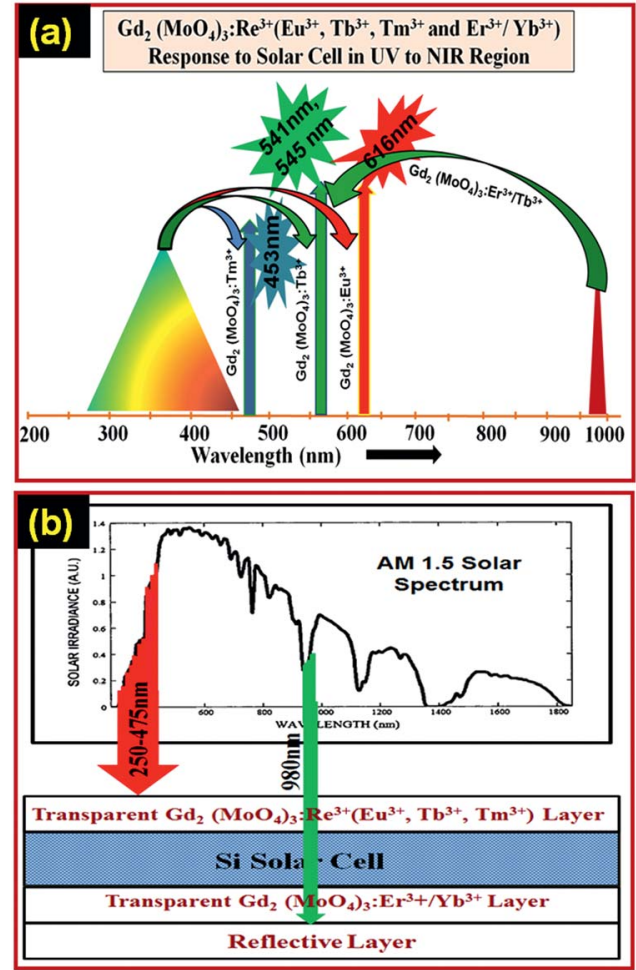

Fig. 6 ( $a$ and b) Proposed schematic diagrams of the $\mathrm{Gd}_{2}\left(\mathrm{MoO}_{4}\right)_{3}$ : $\mathrm{Re}^{3+}\left(\mathrm{Re}^{3+}=\mathrm{Eu}^{3+}, \mathrm{Tb}^{3+}, \mathrm{Tm}^{3+}\right.$ and $\left.\mathrm{Er}^{3+} / \mathrm{Yb}^{3+}\right)$ nanophosphors (downshifts and upconversion) as a broad spectral converter from UV to NIR in order to enhance the efficiency of a Si-solar cell. 
which can be easily absorbed by the Si-solar cell for electronhole pair generation. The NIR region is also not absorbed by solar cells because for the NIR region solar cell is transparent. The $\mathrm{Gd}_{2}\left(\mathrm{MoO}_{4}\right)_{3}: \mathrm{Er}^{3+} / \mathrm{Yb}^{3+}$ upconversion nanophosphor absorbs in the NIR region and emits in the visible region which can be easily absorbed by Si-solar cells. Therefore, the efficiency of the Si-solar cell could be enhanced by coating a thin layer of the downshift nanophosphor on the front side and an upconversion nanophosphor layer on the back side of the Si-solar cell. Fig. 6(a) and (b) illustrate a proposed spectral converter for $\mathrm{Gd}_{2}\left(\mathrm{MoO}_{4}\right)_{3}: \mathrm{Re}^{3+}\left(\mathrm{Re}^{3+}=\mathrm{Eu}^{3+}, \mathrm{Tb}^{3+}, \mathrm{Tm}^{3+}\right.$ and $\left.\mathrm{Er}^{3+} / \mathrm{Yb}^{3+}\right)$ nanophosphors to enhance the efficiency of Si-solar cells. Thus, the obtained spectroscopy results reveal that the $\mathrm{Gd}_{2}\left(\mathrm{MoO}_{4}\right)_{3}$ : $\mathrm{Re}^{3+}\left(\mathrm{Re}^{3+}=\mathrm{Eu}^{3+}, \mathrm{Tb}^{3+}, \mathrm{Tm}^{3+}\right.$ and $\left.\mathrm{Er}^{3+} / \mathrm{Yb}^{3+}\right)$ nanophosphor could be a good choice as a spectral converter for upcoming next generation Si-solar cells.

\section{Conclusions}

We have successfully synthesized $\mathrm{Gd}_{2}\left(\mathrm{MoO}_{4}\right)_{3}: \mathrm{Re}^{3+}\left(\mathrm{Re}^{3+}=\right.$ $\mathrm{Eu}^{3+}, \mathrm{Tb}^{3+}$ and $\mathrm{Tm}^{3+}$ ) (downshift) and $\mathrm{Gd}_{2}\left(\mathrm{MoO}_{4}\right)_{3}: \mathrm{Er}^{3+} / \mathrm{Yb}^{3+}$ (upconversion) nanophosphors by a customized solid state reaction method which can be easily scaled-up for large quantities. The structural and microstructure studies show that the nanophosphors have an orthorhombic crystal structure with an average size in the range of $\sim 24-28 \mathrm{~nm} . \mathrm{Gd}_{2}\left(\mathrm{MoO}_{4}\right)_{3}$ has an advantage over other host matrices as the excitation band is broad due to the charge transfer in O-Mo in the UV region, which sufficiently transfers energy to trivalent lanthanide ions. The $\mathrm{Gd}_{2}\left(\mathrm{MoO}_{4}\right)_{3}: \mathrm{Eu}^{3+}$ downshift nanophosphor demonstrates hypersensitive red emission at $616 \mathrm{~nm}$ corresponding to excitation in the range of $250-475 \mathrm{~nm}$. The $\mathrm{Gd}_{2}\left(\mathrm{MoO}_{4}\right)_{3}: \mathrm{Er}^{3+} / \mathrm{Yb}^{3+}$ upconversion nanophosphor shows strong green emission at $545 \mathrm{~nm}$ upon an excitation of $980 \mathrm{~nm}$. The co-doping of $\mathrm{Yb}^{3+}$ ions assists the broad absorption in the NIR region as $\mathrm{Yb}^{3+}$ ions can absorb a broader range in the NIR region compared to $\mathrm{Er}^{3+}$ ions. Furthermore, the $\mathrm{Gd}_{2}\left(\mathrm{MoO}_{4}\right)_{3}: \mathrm{Er}^{3+} / \mathrm{Yb}^{3+}$ upconversion nanophosphor demonstrates emission at $994 \mathrm{~nm}$, which is rarely reported. Moreover, TRPL spectroscopy demonstrates a PL lifetime of $\tau_{\text {av }} \sim 0.64 \mathrm{~ms}$. Thus, the obtained PL and TRPL spectroscopy results of the synthesized nanophosphor legitimates its potential use as a broad spectral converter for next generation Si-solar cells.

\section{Acknowledgements}

The authors wish to thank Director, N.P.L., New Delhi, for his keen interest in the work. The authors are thankful to Prof. O. N. Srivastava (Banaras Hindu University, Varanasi) for his encouragement. Mr Pawan Kumar gratefully acknowledges the University Grant Commission (UGC), Govt of India, for financial assistance under RGNF Research Fellowship, Award no. F1-17.1/2011-12/RGNF-SC-PUN-12604/(SA-III/Website). The authors are grateful to the CSIR TAPSUN program providing PL mapping instrument facility.

\section{References}

1 G. D. Scholes, G. R. Fleming, A. Olaya-Castro and R. Grondelle, Nat. Chem., 2011, 3, 763-774.

2 N. S. Lewis and D. G. Nocera, Proc. Natl. Acad. Sci. U. S. A., 2006, 103, 15729-15735.

3 O. Morton, Nature, 2006, 443, 19-22.

4 B. M. van der Ende, L. Aartsa and A. Meijerink, Phys. Chem. Chem. Phys., 2009, 11, 11081-11095.

5 X. Huang, S. Han, W. Huang and X. Liu, Chem. Soc. Rev., 2013, 42, 173-201.

6 A. J. Nozik and J. Miller, Chem. Rev., 2010, 110, 6443-6445.

7 H. A. Atwater and A. Polman, Nat. Mater., 2010, 9, 205-213.

8 P. K. Nayak, G. G. Belmonte, A. Kahn, J. Bisquert and D. Cahen, Energy Environ. Sci., 2012, 5, 6022-6039.

9 A. Goetzberger, C. Hebling and H. W. Schock, Mater. Sci. Eng., 2003, 40, 1-46.

10 B. van der Zwaan and A. Rabl, Sol. Energ., 2003, 74, 19-31. 11 B. S. Richards, Sol. Energy Mater. Sol. Cells, 2006, 90, 2329-2337. 12 O. M. ten Kate, M. de Jong, H. T. Hintzen and E. van der Kolk, J. Appl. Phys., 2013, 114, 084502.

13 C. Strumpela, M. McCann, G. Beaucarne, V. Arkhipov, A. Slaoui, V. Svrcek, C. del Canizo and I. Tobias, Sol. Energy Mater. Sol. Cells, 2007, 91, 238-249.

14 T. Trupke, M. A. Green and P. Würfel, J. Appl. Phys., 2002, 92, 4117.

15 H. Q. Wang, M. Batentschuk, A. Osvet, L. Pinna and C. J. Brabec, Adv. Mater., 2011, 23, 2675-2680.

16 S. F. H. Correia, V. de Z. Bermudez, S. J. L. Ribeiro, P. S. Andre, R. A. S. Ferreira and L. D. Carlos, J. Mater. Chem. A, 2014, 2, 5580-5596.

17 W. Guo, K. Zheng, W. Xie, L. Sun, L. Shen, C. Liu, Y. He and Z. Zhang, Sol. Energy Mater. Sol. Cells, 2014, 124, 126-132.

18 S. K. W. MacDougall, A. Ivaturi, J. Marques-Hueso, K. W. Krämer and B. S. Richards, Sol. Energy Mater. Sol. Cells, 2014, 128, 18-26.

19 M. G. Debije and P. P. C. Verbunt, Adv. Energy Mater., 2012, 2, 12-35.

20 J. de Wild, A. Meijerink, J. K. Rath, W. G. J. H. M. van Sark and R. E. I. Schropp, Energy Environ. Sci., 2011, 4, 4835-4848.

21 E. Klampaftis, D. Ross, K. R. McIntosh and B. S. Richards, Sol. Energy Mater. Sol. Cells, 2009, 93, 1182-1194.

22 W. G. J. H. M. van Sark, Renewable Energy, 2013, 49, 207-210.

23 P. F. Scudo, L. Abbondanza, R. Fusco and L. Caccianotti, Sol. Energy Mater. Sol. Cells, 2010, 94, 1241-1246.

24 X. Liu, L. Li, H. M. Noh, B. K. Moon, B. C. Choib and J. H. Jeong, Dalton Trans., 2014, 43, 8814-8825.

25 X. F. Liang, X. Y. Huang and Q. Y. Zhang, J. Fluoresc., 2009, 19, 285-289.

26 P. Kumar, J. Dwivedi and B. K. Gupta, J. Mater. Chem. C, 2014, 2, 10468.

27 B. K. Gupta, D. Haranath, S. Saini, V. N. Singh and V. Shanker, Nanotechnology, 2010, 21, 055607.

28 S. Abtmeyer, R. Pązik, R. J. Wiglusz, M. Małecka, G. A. Seisenbaeva and V. G. Kessler, Inorg. Chem., 2014, 53, 943-951. 
29 A. Dwivedi, A. K. Singh and S. B. Rai, Dalton Trans., 2014, 43, 15906.

30 T. V. Gavrilovic, D. J. Jovanovic, V. Lojpur and M. D. Dramicanin, Sci. Rep., 2014, 4, 4209.

31 B. K. Gupta, N. N. Tharangattu, S. A. Vithayathil, Y. Lee, S. Koshy, A. L. M. Reddy, A. Saha, V. Shanker, V. N. Singh, B. A. Kaipparettu, A. A. Martí and P. M. Ajayan, Small, 2012, 8, 3028-3034.

32 M. Haase and H. Schafer, Angew. Chem., Int. Ed., 2011, 50, 5808-5829.

33 A. Shalav, B. S. Richards, T. Trupke, K. W. Krämer and H. U. Güdel, Appl. Phys. Lett., 2005, 86, 013505.
34 D. Chen, L. Lei, A. Yang, Z. Wang and Y. Wang, Chem. Commun., 2012, 48, 5898-5900.

35 A. C. Pana, C. del Canizo, E. N. M. Santos, J. P. Leitao and A. Luque, Sol. Energy Mater. Sol. Cells, 2010, 94, 1923-1926.

36 K. Mishra, S. K. Singh, A. K. Singh, M. Rai, B. K. Gupta and S. B. Rai, Inorg. Chem., 2014, 53, 9561-9569.

37 F. Lahoz, C. P. Rodriguez, S. E. Hernandez, I. R. Martın, V. Lavin and U. R. R. Mendoza, Sol. Energy Mater. Sol. Cells, 2011, 95, 1671-1677.

38 Y. Y. Cheng, B. Fuckel, R. W. MacQueen, T. Khoury, R. G. C. R. Clady, T. F. Schulze, N. J. E. Daukes, M. J. Crossley, B. Stannowski, K. Lips and T. W. Schmidt, Energy Environ. Sci., 2012, 5, 6953-6959. 